\author{
Article Type: Research Article Year: $2020 \quad$ V/I: 6(1) Pages: 1-16 \\ Corresponding Author: Ümmügülsüm Y1lmaz / cihangiroglu.pdr@gmail.com \\ DOI: http://dx.doi.org/10.19148/ijhbs. 746707 \\ Citation Information: \\ Y1lmaz, Ü. \& Türk, F. (2020). The Effect of Peer Mediation Training on Self-Efficacy, Locus \\ of Control and Conflict Resolution Skills. The International Journal of Human and Behavioral \\ Science, 6(1), 1-16. doi: 10.19148/ijhbs.746707
}

Received: 01/06/2020

Accepted: 02/07/2020

Published: 26/08/2020

\title{
The Effect of Peer Mediation Training on Self-Efficacy, Locus of Control and Conflict Resolution Skills
}

\author{
Ümmügülsüm YILMAZ, Ministry of Education, Turkey \\ ORCID: https://orcid.org/0000-0002-3029-2927 \\ Fulya TÜRK, Gaziantep University, Turkey \\ ORCID: https://orcid.org/0000-0003-1896-8418
}

\begin{abstract}
Peer mediation is an effective method for individuals to solve interpersonal conflicts in constructive ways. The aim of this study is to investigate the effect of peer mediation training on self-efficacy, locus of control and conflict resolution on secondary school students. Pretest-posttest-tracing test quasi-experimental design method was used in the study. The research was carried out on the sixth-grade students of two secondary schools in Şehitkamil district of Gaziantep. In this research, two study groups, consisting of 24 students, 12 of which were experimental and 12 control groups, were formed. "Conflict Resolution Scale", "Locus of Control Scale" and "Children's Self-Efficacy Scale" were applied as pre-test, post-test and follow-up test to the experimental and control groups. Peer mediation training was given only to the experimental group during 10 sessions. Mann-Whitney U and Wilcoxon Signed Ranks Test method was used for data analysis. Results showed that after mediation training, self-efficacy levels of students, internal locus of control and conflict resolution skills increased. In conclusion, it was determined that students who have taken the peer mediation training have more effective conflict resolution skills, internal locus of control and self-efficacy levels in comparison with those of students who have not taken this training.
\end{abstract}

Keywords: peer mediation, conflict resolution, self-efficacy, locus of control

\section{Introduction}

Schools are institutions with a complex and dynamic structure with a wide variety of dissimilar individuals from students, teachers and administrators to staff members and custodians. This diversity is an inevitable result of all behaviors, thoughts and emotions of people related with perceptions, needs, values, power desires, goals, opinions and human relations (Kite, 2007). Conflicts inevitably take place when it is considered that it is impossible for the wishes, desire, values and requirements of people to overlap throughout their lives. Conflicts make up an indispensable part of daily life and are also indicators of a healthy community (Kite, 2007; Türnüklü, 2007). Conflicts, differences of opinions and problems that date as far back as humanity emerge almost in any relationship (Moore, 2016). Hence, it is only natural that conflicts take place at schools when it is considered that they are a small reflection of social life. Since secondary school can be considered as the start of a period of time during which individuals are in search of something and are in frequent conflicts with their families, environment the community they live 
in, it is possible to state that conflicts due to differences will inevitably emerge during this period (Cüceloğlu, 2011).

Schools can be considered as second homes in the lives of students as an important location where they spend a significant amount of their daily life. The presence of violence at such an important location that should provide a safe environment to support the healthy development of children may result in adverse impacts on the students. Hence, friendship relations that are important as foundations of trust especially during adolescence can be affected negatively. Schools that are responsible from the education of students should be prepared against the interpersonal conflicts among students that are inevitable and natural (Bush \& Folger, 2013; Çetin, et al., 2015; Gülkokan, 2011; Taştan, 2004; Türk, 2008; 2013; Türnüklü \& Şahin, 2002; 2004).

Majority of the conflicts that take place at schools are resolved by adults generally by the use of force. Students are warned not to display the undesired behaviors again. Thus, both the school administration and the teachers expect that the warnings will eliminate the undesired behaviors of students. However, the management and control of emotions and behaviors by the external environment may lead to discomfort in the individual resulting in resistance and refusal of control. The ability of such directives, advices and counsels to guide towards achieving the desired behaviors is also very low. Because they emphasize what should be done instead of focusing on guiding the individuals towards acquiring the information and skills related with what should be done. Students acquire the correct behaviors over time by doing and experiencing hence leading to permanent behaviors. When it is considered that majority of the students come to schools without displaying the required social and emotional development in their families, the importance of the responsibility of the schools for ensuring that students acquire the required constructive conflict resolution skills gains further significance (Gülkokan, 2011; Özmen, 2004; Türnüklü \& Bekmezci, 2010).

The reactions of students towards conflicts are closely related with their past experiences, their perspectives related with conflict, how people around them resolve conflicts and the individuals that students consider as models. If the student sees that destructive solutions resolve his/her conflicts, he/she will prefer to continue this type of behaviors. However, if the student is taught constructive means to resolve conflicts, he/she will add these behaviors to his/her repertoire and transform them into skills that will be used throughout his/her life. At this point, the duty of the school should be to teach the students constructive conflict resolution methods. For this purpose, conflict resolution and peer mediation programs can be used at schools (Taştan, 2004; 2006).

Students will be able to take on the responsibility of their own conflicts and resolve them personally by way of peer mediation programs. It will also help in eliminating any negativities involved when the school administration or an adult such as their teachers decide for themselves and resolve their conflicts on behalf of the students. The self-confidence of the student will increase further when he/she takes on the responsibility of the conflict and resolves it through democratic means according to his/her own decisions thereby improving self-control and transforming them into useful skills that will be necessary throughout his/her life. Moreover, the interpersonal relations of the students will not be affected when he/she resolves the conflicts constructively. Thus, it can be stated that implementing peer mediation programs at schools is important since it enables the students with advanced interpersonal skills to express themselves more comfortably and resolve their problems before they escalate any further.

Students will find it possible to feel successful in conflict resolution thanks to peer mediation programs that can be considered to provide the best support to the students for resolving their own conflicts and to transform conflict resolution into a skill. It is apparent that the self-efficacy perception of the student will be supported positively when he/she feels successful in resolving conflicts. In the meantime, the student will have also contributed to strengthening his/her sense 
of control on his/her behaviors as he/she continues to resolve his/her own conflicts as well as contributing to the development of his/her internal locus of control. When considered from this perspective, it can be stated that the implementation of peer mediation trainings at schools holds significant importance.

Türnüklü and Şahin (2002) carried out a study putting forth that the conflicts between students are generally tried to be resolved by the teachers through the use of authority. The teachers have stated that they spend a lot of time to resolve conflicts. It is also among the findings that teachers generally take on the responsibility for resolving the conflicts started by the students among themselves, that generally teachers try to end the conflict through their own decisions, that the win-lose method is generally preferred and that conflicts are generally tried to be resolved through the inspection of a third person. These implementations lead to students not taking on the responsibility of resolving the conflicts through negotiations thereby resulting in the inability of their internal control to develop (Noaks \& Noaks, 2009). However, the self-confidence of students increase when they manage to resolve their own conflicts by themselves without any directives from adults or traditional methods such as award and punishment thereby improving their internal control rather than making them dependent on external control. This study by Türnüklü and Şahin (2002) is also an indication that it is necessary to include conflict resolution and peer mediation programs in the curricula of schools that teach the students conflict resolution strategies encouraging internal control, self-management and internal discipline.

It is observed when the general objectives of the Turkish National Education indicated in the National Education Basic Law numbered 1739 that the emphasis is not only on ensuring that the students improve themselves academically to learn a profession but also to have a balanced personality with regard to spirit and emotions that is beneficial for the society they live in. It is put forth here that it is necessary to improve the students academically while also equipping them with the necessary life skills. Democracy education is also emphasized in the same law as part of the fundamental principles of National Education, in addition to mentioning the necessity of including innovations and advancements in accordance with scientific studies on education. It is apparent that peer mediation programs should be implemented at schools as programs with the necessary attributes for improving the communication, anger management, empathy and negotiation skills of students that will enable them to develop the skill of resorting to democratic means in solving problems. However, the implementation of such programs is unfortunately not very common in our country as of yet (Çetin, et al., 2015). There may be cases in secondary schools when the emphasis is placed on preparing the students for high school examinations resulting in pushing back the activities that will support their development in all areas. However, schools also need to include activities that will equip the students with many different skills such as peer mediation that will provide them with life skills thus supporting their multi-dimensional development instead of acting only as institutions that prepare the students for examinations. The returns of conflict resolution and peer mediation program are in full accordance with the National Education Basic Law numbered 1739.

Even though students may not use the knowledge they acquire during courses such as Mathematics or Turkish at every stage of their daily lives, their conflict resolution skills will support them wherever they go. Students who are able to resolve their conflicts in a constructive manner will be more successful in interpersonal relationships. In this regard, it is apparent that the implementation of conflict resolution and peer mediation program at schools will contribute to the personal development of students (Türnüklü, 2005). Students will be able to resolve their own conflicts thanks to the implementation of peer mediation program instead of resorting to the guidance department, their teachers or the school administration in cases of interpersonal conflicts. This will result in eliminating interpersonal problems from the focus of guidance activities thereby making it possible to spare more time to rehabilitative, preventive and enhancing activities. Similarly, it will also enable the teachers and the school administration to 
save time for educational and instructional activities. Thus, it will contribute to further increasing the quality of education and instruction at schools.

Conflict resolution and peer mediation trainings have been used in many different studies and it has been observed to make an impact on skills such as conflict resolution (Ateş, 2014; Arslan, 2014; Çavuş-Kasik, 2012; Çoşkuner, 2008; Damirchi, 2014; Göğgebakan-Yıldız, 2016; Gülkokan, 2011; Hart \& Gunty, 1977; İspirgil, 2007; Johnson,et al., 1997; Johnson, et al., 1995; Kılıçarslan \& Atıc1, 2015; Koruklu, 1998; Kutlu, 2016; Sağkal, 2011; Stevahn, et al., 1996; Şevkin, 2008; Tapan, 2006; Taştan, 2004; Türk, 2008; Türnüklü, 2008; Türnüklü et al., 2010; Uysal, 2003; Zengin, 2008), aggressiveness (Çoşkuner, 2008; Sağkal, 2011; Şevkin, 2008; Türnüklü et al., 2010; Uysal, 2003), anger (Kutlu, 2016), empathy (Lane-Garon, Ybarra-Merlo et al., 2005; Sağkal, 2011; Schaeffer \& Rollin, 2001; Türk, 2008; Türnüklü et al., 2009). Hence, it is observed that the peer mediation model should be considered not only as a model for preventing and reducing violence but also a model that contributes to the social emotional development of children and adolescents. Different from the other studies, the importance of examining its impact on locus of control and self-efficacy as important social and emotional skills is observed in the present study. Positive findings acquired from this study will put forth not only why the conflict resolution and peer mediation model is necessary but also that it makes significant contributions to the personal development of students/young individuals. Thus, it will be put forth that peer mediation training is not only a model for preventing violence but that it is also an important element of social and emotional development. Abdi-Golzar (2006) carried out a study in which it was put forth that successful students are more responsible than unsuccessful students and that students with high levels of responsibility have internal control. Based on this finding, it is considered that students who are raised as peer mediators as a result of conflict resolution and peer mediation training will take on the responsibility of helping their peers in resolving their conflicts hence contributing to their internal control. Moreover, helping their peers in resolving their conflicts will also increase the responsibility levels of the students thereby contributing to increasing their internal control. It can be stated that the confidence of the students in their own skills will increase when they are able to resolve their conflicts successfully which will in turn increase their self-efficacy perception levels.

\subsection{Objectives and Hypotheses}

Thus, based on all these reasons, it was aimed in the present study to examine the impact of peer mediation training on self-efficacy, locus of control and conflict resolution skill. For this purpose, the following hypotheses were tested:

1. There is a statistically significant difference between the conflict resolution skills pre-test, post-test and follow-up test scores of students who have and have not taken the peer mediation training.

2. There is a statistically significant difference between the locus of control pre-test, post-test and follow-up test scores of students who have and have not taken the peer mediation training.

3. There is a statistically significant difference between the academic, social, emotional and general self-efficacy pre-test, post-test and follow-up test scores of students who have and have not taken the peer mediation training

\section{Method}

\subsection{Study Model}

Pre-test-post-test-follow-up test control group semi-experimental pattern was used in the present study to examine the impact of peer mediation training on self-efficacy, locus of control and conflict resolution skills. The subjects were selected in this study based on the sociometry results taking into consideration the distribution of female-male subjects after which the subjects were 
assigned randomly to the experimental and control groups. The independent variable in this study is peer mediation training. Whereas the dependent variables are self-efficacy level locus of control level and conflict resolution skill.

\subsubsection{Participants}

The study was carried out at two Ministry of Education secondary schools with similar characteristics at Şehitkamil district of the Gaziantep province. The study group was comprised of students selected from among the sixth graders at these schools. Two study groups were prepared namely as the experimental and control groups each comprised of 12 students. The experimental group students were selected from one of the schools included in the study, while the control group students were selected from the other school. The reason for selecting the students of different groups from different schools was to minimize the impact of the interactions between the students who are and are not subject to this training.

Sociometry was applied to the students while preparing the study groups. The sociometry question directed at the students was: "Can you write down the names of three classmates you trust and you would want help from in order to resolve the interpersonal conflicts with your friends?". Sociometries were applied to all students in all sixth grade classes at both schools without providing any information on the study after which the results were evaluated.

There were three classes in the secondary school from where the experimental group students were selected. A total of 15 students were selected with five students from each class by taking into consideration the female-male distribution among those with the highest sociometry scores. The number of sixth grade classes was six in the secondary school from where the control group students were selected. Two students were selected from two random classes among these; whereas three students were selected from each of the remaining classes making up a total of 15 students in the control group.

All of the male students (total of three students) included in the study from the "B" class of the experimental group school wanted to leave the group after two sessions. Thus, the experimental group was left with 12 students. Whereas three students from the control group were excluded from the study since post-test and follow-up test could not be applied due to school change. Thereby, the control group was also left with 12 students. As a result, the study was carried out with 12 students ( 7 female, 5 male) in the experimental group and 12 students ( 6 female, 6 male) in the control group making up a total of 24 students.

\subsection{Instruments}

\subsubsection{Self-Efficacy Scale for Children}

The Scale developed by Murris (2001) and adapted into Turkish by Telef (2011) was used for measuring the self-efficacy level as the dependent variable of the study. Telef (2011) determined three sub-dimensions in the Scale as social, academic and emotional. The Scale is comprised of a total of 21 items with seven items in each sub-dimension. The score calculated based on the responses to all items indicate the total self-efficacy level. The lowest score that can be obtained from the Scale is 21 , whereas the highest score is 105 . High scores obtained from the Scale indicate that the individual has a high self-efficacy level, whereas low scores indicate a low selfefficacy level (Telef, 2011).

Telef (2011) carried out exploratory and confirmatory factor analysis to determine the construct validity of the Scale. The variance ratios obtained as a result of the exploratory factor analysis were $25,52 \%$ for academic self-efficacy, $10,49 \%$ for social self-efficacy and 7,64\% for emotional self-efficacy while the total explained variance ratio was determined as $43,74 \%$. The Eigen values regarding the factor common variance of the Scale items were determined to vary between .612 
and .305 . While the fit index values were determined as a result of confirmatory factor analysis as $\mathrm{GFI}=.94, \mathrm{NFI}=.95, \mathrm{CFI}=.96, \mathrm{SRMR}=.066$ and $\mathrm{RMSEA}=.049$. The values calculated for determining the internal consistency coefficient of the Scale were determined as $\alpha=.86$ for the Scale in general, $\alpha=.84$ for academic self-efficacy, $\alpha=.64$ for social self-efficacy and $a=.78$ for emotional self-efficacy (Telef, 2011).

\subsubsection{Locus of Control Scale}

The Likert type Locus of Control Scale developed by Dağ (2002) was used for measuring the locus of control which is another dependent variable of the study. The researcher prepared a pool comprised of 80 comprehensive items during the development period of the Scale put forth by either taking the same or revised items from already existing locus of control scales. The 80 item form developed was applied to a group of 272 individuals as a result of which the Locus of Control Scale comprised of 47 items was obtained following the item analyses using the acquired data (Dağ, 2002). The Locus of Control Scale developed by Dağ (2002) was comprised of five factors named as "auto control", "belief in luck", "meaningfulness of striving", "fatalism" and "unfair world belief ". Increase in scores indicates the locus of control, while decreasing scores signify an internal locus of control. The highest score that can be obtained from the scale is 47 , while the highest score is 235 (Dăg, 2002).

Dağ (2002) calculated the internal consistency coefficient of the scale as $\alpha=.92$. It was observed that the correlation value calculated between the developed Locus of Control Scale and that of Rotter's Internal-External Locus of Control Scale was .67; or that in other words both scales share a variance of $45 \%$ (Dağ, 2002).

\subsubsection{Conflict Resolution Scale}

Conflict Resolution Scale developed by McClellan (1997) and adapted into Turkish by Taştan (2004) was used for measuring the conflict resolution skill which is one of the dependent variables. This 40 item scale adapted by the researcher is comprised of 10 sub-dimensions. The scale is scored as five-point Likert type (Taştan, 2004). Two factors named as "constructive conflict resolution approach" and "destructive conflict resolution approach" were determined as a result of the factor analysis for the scale (Taştan, 2004).

It was observed when the coefficients obtained by the researcher regarding the reliability of the scale were examined that the total score is .74 , that the score for constructive conflict resolution approach is .75 and that the score for destructive conflict resolution method is .74. Hence, it was concluded that the scale yields consistent results. The researcher calculated the internal consistency coefficients as .82 for the constructive conflict resolution approach as the first subdimension of the scale and as .73 for the destructive conflict resolution approach as the second sub-dimension (Taştan, 2004).

\subsection{Peer Mediation Training Program}

The "Peer Mediation Training Program" developed by Türk, Türkmen, Satıcı, Başol and Gümüş (2015) was applied to the experimental group students during the study. The researchers developed two separate books for the students and the psychological counselor. Student books are used for implementation. There are a total of 17 activities in the training program comprised of 10 sessions. Each session has been planned as 80 minutes.

The program developed by Türk et al. (2015) is comprised of four main skills of "understanding the nature of the conflict ", "communication skills", "anger management skills" and "negotiation and peer mediation skills". Explanatory information has been provided below on the four main skills included in the peer mediation training program included in the study:

1. Understanding the Nature of the Conflict: The objective here is to ensure that the students gain the skills and knowledge related with the nature of the conflicts and misunderstandings 
that inevitably develop during interpersonal relations. For this purpose, knowledge and skills were tried to be provided regarding the determination of the associations related with the conflict, understanding the nature of the interpersonal conflict, noticing conflict $2 \mathrm{~s}$ gains, learning the reasons of the conflict and the reactions given to the conflict along with the skills and knowledge related with analyzing interpersonal conflicts.

2. Communication Skills: The objective in this section is to ensure that the students gain the fundamental communication skills to resolve the conflicts in a constructive manner rather than a destructive manner involving violence. For this purpose, knowledge and skills related with effective listening, body language, empathy and self-awareness were included.

3. Anger Management Skills: Individuals generally experience a sense of anger during conflicts which prevents the constructive resolution of the conflict. For this purpose, it is important in order to be an effective mediator to identify anger and to learn how to behave without disrupting interpersonal relations during conflicts. This section includes information on subjects such as anger awareness, words and behaviors that increase the anger, use of the 'I' language and anger control.

4. Negotiation and Peer Mediation Skills: The objective in this section was to teach the students the necessary negotiation skills that will enable them to resolve their conflicts in a constructive manner as well as the mediation skills that will enable them to resolve the conflicts of their peers. For this purpose; subjects of learning and implementing the steps of negotiation, learning about mediation and the steps of mediation as well as the evaluation of mediation steps have been included.

\subsection{Procedure}

Before starting the studies, legal and ethical permissions were obtained for the research. The pilot application for the peer mediation program was carried out by the primary author at the secondary school where she works as a psychological counsel. The fact that the pilot application was carried out at the institution where the researcher works made it easier to implement the training program as well as to determine the negativities experienced during the actual peer conflict resolution stage at the end of the implementation due to the easy access to the students. Sociometry was applied to all classes at the sixth grade level during the start of the implementation. Students to be included in the peer mediation training were determined from among the most preferred students based on the sociometry results also taking into consideration the female-male distribution. The study was carried out with a total of 18 students with three from each classroom of the six sixth grade classes. The evaluations of the students, observations and evaluations of the implementer with regard to the process were examined together with the second author at the end of each session and the defective parts of the program were determined by the primary and second author. Revisions were made at the end of each session with regard to the defective parts. Moreover, a general assessment was made together with the students at the end of the sessions and student opinions were taken with regard to the program.

After pilot application, the study was carried out. Cadre approach was used in this research. Therefore, a limited number of students were educated instead of all students in the class. Sociometry was applied to all sixth grade classes of the experimental and control group schools. Students were selected for the experimental and control groups as a result of the application from among the most preferred students also taking into consideration the female-male distribution. First of all, the Conflict Resolution Scale, Locus of Control Scale and Self-Efficacy Scale for Children were applied to the experimental and control groups as pre-test. This was followed by a 10 session peer mediation training given to the experimental group by the primary author. Even though 2 sessions were conducted in certain weeks due to official holidays, exam weeks, ceremonies etc., the training was carried out mostly with one session per week. The control group was not subject to any application during this period of time. The Conflict Resolution Scale, Locus of Control Scale and Self-Efficacy Scale for Children were applied once again to both groups after the training. The Conflict Resolution Scale, Locus of Control Scale and Self-Efficacy Scale 
for Children were applied once again to the experimental and control groups as follow up test six months after the end of the peer mediation training applications in order to determine whether the effectiveness of the peer mediation training is sustained over long periods of time. The experimental and control groups were planned to include 15 individuals each, however the study was completed with 12 students in each group.

\subsection{Data Analysis}

Quantitative data analysis was used for determining the impact of peer mediation training on selfefficacy, locus of control and conflict resolution skills. The study data were analyzed via SPSS 20 software. Mann-Whitney from among the non-parametric statistical methods was used on the values obtained from the scales since the normality assumption was not met during the statistical operations and because the number of students included in the study was below 30 . Wilcoxon Signed Ranks Test was used for determining whether the results obtained by the experiment and control groups from the pre-test-post-test-follow-up test varied at a statistically significant level internally.

The reason for using the Wilcoxon Signed Ranks Test instead of the Friedman Test was the desire to observe the difference between the follow-up test scores after the post-test scores of students included in the experimental group who were raised as peer mediators helped them in resolving the actual conflicts of their peers.

The effect size values regarding the changes between the pre-test and post-test as well as between the post-test and follow-up test scores of the study groups were calculated and presented in the related tables. Effect size is the unit of the strength of the relationship between two variables (Borenstein et al., 2009). The effect is low if the effect size intervals are $r<0.20$, moderate if the effect size intervals are between $20<r<50$ and high if the effect size is $r>50$ (Cohen, 1988).

\section{Findings}

The purpose of the present study was to examine the impact of peer mediation training on conflict resolution skill, locus of control and self-efficacy. First, the arithmetic averages and standard deviations were calculated for the scores obtained by the experimental and control groups from the Conflict Resolution Scale, Locus of Control Scale and Self-Efficacy Scale for Children before and after the operation. Table 1 presents the acquired results.

Table 1. Descriptive results of the experimental and control groups for the CRS, LCS and SESC pre- test and post-test and follow-up test

\begin{tabular}{|c|c|c|c|c|c|c|c|c|}
\hline \multirow{2}{*}{$\begin{array}{l}\text { Measures } \\
\text { Groups }\end{array}$} & & \multirow{2}{*}{$\mathbf{N}$} & \multicolumn{2}{|c|}{ Pre-Test } & \multicolumn{2}{|c|}{ Post-Test } & \multicolumn{2}{|c|}{ Follow-up Test } \\
\hline & & & $\bar{X}$ & Sd & $\overline{\mathrm{X}}$ & Ss & $\overline{\mathrm{X}}$ & Ss \\
\hline \multirow{2}{*}{ CRS } & Experimental & 12 & 137.17 & 14.88 & 152.42 & 17.38 & 153.08 & 13.28 \\
\hline & Control & 12 & 141.92 & 11.03 & 140.00 & 8.78 & 142.67 & 16.06 \\
\hline \multirow{3}{*}{ LCS } & Experimental & 12 & 120.00 & 20.45 & 97.83 & 18.93 & 94.75 & 21.76 \\
\hline & Control & 12 & 111.67 & 15.59 & 115.25 & 14.19 & 111.00 & 20.37 \\
\hline & Experimental & 12 & 74.50 & 7.50 & 87.50 & 10.83 & 89.58 & 7.53 \\
\hline SESC & Control & 12 & 71.42 & 10.08 & 72.83 & 10.94 & 71.58 & 15.06 \\
\hline
\end{tabular}

CRS: Conflict Resolution Scale, LCS: Locus of Control Scale, SESC: Self-Efficacy Scale for Children

A greater increase is observed in the pre-test, post-test and follow-up test averages of the experimental group in Table 1 compared with the Conflict Resolution Scale pre-test, post-test and follow-up test score averages of the control group. It is observed when the Locus of Control Scale is examined that there is a decrease in the pre-test, post-test and follow-up test scores for the locus of control. Similarly, an increase is observed in the pre-test, post-test and follow-up test scores 
for the Conflict Resolution Scale of the experimental group after the pre-test. A significant difference was not observed between the experimental and control groups.

Mann-Whitney U Test analysis was carried out for determining whether there is a statistically significant difference between the pre-test scores of the students in the experimental and control groups obtained from the Conflict Resolution Scale, Locus of Control Scale and Self-Efficacy Scale for Children. Table 2 presents the results of the analysis.

Table 2.CRS, LCS and SESC pre-test Mann-Whitney $U$ test results for the experimental and control groups

\begin{tabular}{llllllll}
\hline \multirow{2}{*}{ Measures } & \multicolumn{2}{c}{ Experimental } & \multicolumn{2}{c}{ Control } & \multirow{2}{*}{} & & \multirow{2}{*}{ p } \\
& Mean Rank & Sum of Rank & Mean Rank & Sum of Rank & & & \\
\hline CRS & 11.50 & 138.00 & 13.50 & 162.00 & 60.00 & .488 \\
LCS & 16.00 & 240.00 & 15.00 & 225.00 & 105.00 & .75 \\
SESC & 15.43 & 231.50 & 16.53 & 264.50 & 111.50 & .74 \\
\hline
\end{tabular}

It can be indicated upon examining Table 2 that the conflict resolution, locus of control and selfefficacy pre-test scores of the experimental and control groups do not differ at a statistically significant level. In other words, it can be stated that the conflict resolution, locus of control and self-efficacy levels of both groups are similar before the experimental.

Table 3 presents the Wilcoxon Signed Ranks Test results regarding the pre-test and post-test as well as post-test and follow-up test conflict resolution scores of the experimental and control groups.

Table 3. Wilcoxon Signed Ranks Test Results for the Conflict resolution Pre-test-Post-test and Posttest-Follow-Up Test Scores of the Experimental and Control Groups

\begin{tabular}{|c|c|c|c|c|c|c|c|c|}
\hline Group & Measure & & n & Mean Rank & Sum of Rank & $\mathbf{Z}$ & p & $\mathbf{r}$ \\
\hline \multirow{6}{*}{ Experimental } & \multirow{3}{*}{$\begin{array}{l}\text { Pre-test- } \\
\text { Post-Test }\end{array}$} & Negative Ranks & 1 & 1.00 & 1.00 & \multirow{3}{*}{2.982} & \multirow{3}{*}{.003} & \multirow{3}{*}{.86} \\
\hline & & Positive Ranks & 11 & 7.00 & 77.00 & & & \\
\hline & & Ties & 0 & & & & & \\
\hline & \multirow{3}{*}{$\begin{array}{l}\text { Post-test- } \\
\text { Follow-up }\end{array}$} & Negative Ranks & 5 & 7.30 & 36.50 & \multirow{3}{*}{.196} & \multirow{3}{*}{.844} & \multirow{3}{*}{.06} \\
\hline & & Positive Ranks & 7 & 5.93 & 41.50 & & & \\
\hline & & Ties & 0 & & & & & \\
\hline \multirow{6}{*}{ Control } & \multirow{3}{*}{$\begin{array}{l}\text { Pre-test- } \\
\text { Post-Test }\end{array}$} & Negative Ranks & 8 & 5.50 & 44.00 & \multirow{3}{*}{1.684} & \multirow{3}{*}{.092} & \multirow{3}{*}{.49} \\
\hline & & Positive Ranks & 2 & 5.50 & 11.00 & & & \\
\hline & & Ties & 2 & & & & & \\
\hline & \multirow{3}{*}{$\begin{array}{l}\text { Post-test- } \\
\text { Follow-up }\end{array}$} & Negative Ranks & 5 & 5.30 & 26.50 & \multirow{3}{*}{.982} & \multirow{3}{*}{.326} & \multirow{3}{*}{.28} \\
\hline & & Positive Ranks & 7 & 7.36 & 51.50 & & & \\
\hline & & Ties & 0 & & & & & \\
\hline
\end{tabular}

It can be put forth upon examining Table 3 that the increase between the Conflict Resolution Scale pre-test and post-test scores of the experimental group is statistically significant $(\mathrm{z}=2.982 ; \mathrm{p}<$ $0.05, \mathrm{r}=.86$ ); whereas the difference between the post-test and follow-up test scores is not statistically significant $(\mathrm{z}=.196 ; \mathrm{p}>0.05 \mathrm{r}=.06)$. While a statistically significant difference could not be observed between the Conflict Resolution Scale pre-test and post-test scores of the control group $(\mathrm{z}=1.684 ; \mathrm{p}>0.05 \mathrm{r}=.49)$; and similarly there was also no statistically significant difference between the post-test and follow-up test scores $(\mathrm{z}=.982 ; \mathrm{p}>0.05, \mathrm{r}=.28)$. Thus, it can be stated that the peer mediation training has been effective in the difference between the conflict resolution pre-test and post-test scores of the experimental group and that the impact has also continued for the follow-up measurements.

Table 4 presents the Wilcoxon Signed Ranks Test results regarding the pre-test and post-test as well as post-test and follow-up test locus of control scores of the experimental and control groups. 
Table 4. Wilcoxon Signed Ranks Test Results for the Locus of control Pre-test-Post-test and Posttest-Follow-Up Test Scores of the Experimental and Control Groups

\begin{tabular}{|c|c|c|c|c|c|c|c|c|}
\hline Group & Measure & & n & Mean Rank & Sum of Rank & $\mathbf{Z}$ & $\mathbf{p}$ & $\mathbf{r}$ \\
\hline \multirow{6}{*}{ Experimental } & \multirow{3}{*}{$\begin{array}{l}\text { Pre-test- } \\
\text { Post-Test }\end{array}$} & Negative Ranks & 10 & 6.70 & 67.00 & \multirow{3}{*}{2.197} & \multirow{3}{*}{.028} & \multirow{3}{*}{.63} \\
\hline & & Positive Ranks & 2 & 5.50 & 11.00 & & & \\
\hline & & Ties & 0 & & & & & \\
\hline & \multirow{3}{*}{$\begin{array}{l}\text { Post-test- } \\
\text { Follow-up }\end{array}$} & Negative Ranks & 8 & 5.50 & 44.00 & \multirow{3}{*}{.392} & \multirow{3}{*}{.695} & \multirow{3}{*}{.11} \\
\hline & & Positive Ranks & 4 & 8.50 & 34.00 & & & \\
\hline & & Ties & 0 & & & & & \\
\hline \multirow{6}{*}{ Control } & \multirow{3}{*}{$\begin{array}{l}\text { Pre-test- } \\
\text { Post-Test }\end{array}$} & Negative Ranks & 4 & 7.25 & 55.00 & \multirow{3}{*}{.785} & \multirow{3}{*}{.209} & \multirow{3}{*}{.23} \\
\hline & & Positive Ranks & 8 & 6.13 & 23.00 & & & \\
\hline & & Ties & 0 & & & & & \\
\hline & \multirow{3}{*}{$\begin{array}{l}\text { Post-test- } \\
\text { Follow-up }\end{array}$} & Negative Ranks & 9 & 6.11 & 55.00 & \multirow{3}{*}{1.255} & \multirow{3}{*}{.209} & \multirow{3}{*}{.36} \\
\hline & & Positive Ranks & 3 & 7.67 & 23.00 & & & \\
\hline & & Ties & 0 & & & & & \\
\hline
\end{tabular}

The decrease between the Locus of Control Scale pre-test and post-test scores of the experimental group is statistically significant based on the results presented in Table $4(\mathrm{z}=2.197 ; \mathrm{p}<0.05$, $\mathrm{r}=.63$ ); while the difference between the post-test and follow-up test scores is not statistically significant $(\mathrm{z}=.392 ; \mathrm{p}>0.05, \mathrm{r}=.11)$. It is also understood that the increase between the Locus of Control Scale pre-test and post-test scores of the control group is not statistically significant $(\mathrm{z}=.785 ; \mathrm{p}>0.05, \mathrm{r}=.23)$; and similarly that there is no statistically significant difference between the post-test and follow-up test scores $(\mathrm{z}=1.255 ; \mathrm{p}>0.05, \mathrm{r}=.36)$. Thus, it can be stated that the peer mediation training has been effective in the difference between the locus of control pre-test and post-test scores of the experimental group and that the impact has also continued for the follow-up measurements.

Table 5 presents the Wilcoxon Signed Ranks Test results regarding the pre-test and post-test as well as post-test and follow-up test self-efficacy scores of the experimental and control groups.

Table 5. Wilcoxon Signed Ranks Test results for the Self-Efficacy pre-test and post-test and post-test and follow-up test scores of the experimental and control groups

\begin{tabular}{|c|c|c|c|c|c|c|c|c|}
\hline Group & Measure & & $\mathbf{n}$ & Mean Rank & Sum of Rank & $\mathbf{z}$ & p & $\mathbf{r}$ \\
\hline \multirow{6}{*}{ Experimental } & \multirow{3}{*}{$\begin{array}{l}\text { Pre-test- } \\
\text { Post-Test }\end{array}$} & Negative Ranks & 1 & 2.00 & 2.00 & \multirow{3}{*}{2.904} & \multirow{3}{*}{.004} & \multirow{3}{*}{.84} \\
\hline & & Positive Ranks & 11 & 6.91 & 76.00 & & & \\
\hline & & Ties & 0 & & & & & \\
\hline & \multirow{3}{*}{$\begin{array}{l}\text { Post-test- } \\
\text { Follow-up }\end{array}$} & Negative Ranks & 5 & 5.80 & 29.00 & \multirow{3}{*}{.785} & \multirow{3}{*}{.432} & \multirow{3}{*}{.23} \\
\hline & & Positive Ranks & 7 & 7.00 & 49.00 & & & \\
\hline & & Ties & 0 & & & & & \\
\hline \multirow{5}{*}{ Control } & \multirow{3}{*}{$\begin{array}{l}\text { Pre-test- } \\
\text { Post-Test }\end{array}$} & Negative Ranks & 5 & 6.40 & 32.00 & \multirow{3}{*}{.550} & \multirow{3}{*}{.583} & \multirow{3}{*}{.16} \\
\hline & & Positive Ranks & 7 & 6.57 & 46.00 & & & \\
\hline & & Ties & 0 & & & & & \\
\hline & \multirow[b]{2}{*}{$\begin{array}{l}\text { Post-test- } \\
\text { Follow-up }\end{array}$} & Negative Ranks & 8 & 6.19 & 49.50 & \multirow[b]{2}{*}{.824} & \multirow[b]{2}{*}{.410} & \multirow[b]{2}{*}{.24} \\
\hline & & $\begin{array}{l}\text { Positive Ranks } \\
\text { Ties }\end{array}$ & & & & & & \\
\hline
\end{tabular}

It is observed when Table 5 is examined that the increase between the Self-Efficacy Scale for Children total self-efficacy pre-test and post-test scores of the experimental group is statistically significant ( $\mathrm{z}=2.904 ; \mathrm{p}<0.05, \mathrm{r}=.84)$; while the difference between the post-test and follow-up test scores is not statistically significant $(\mathrm{z}=.785 ; \mathrm{p}>0.05, \mathrm{r}=.23)$. It was also observed that the increase between the Self-Efficacy Scale for Children total self-efficacy pre-test and post-test scores of the control group is not statistically significant $(\mathrm{z}=.550 ; \mathrm{p}>0.05, \mathrm{r}=.16)$; and that similarly the difference between the post-test and follow-up test scores is also not statistically significant $(\mathrm{z}=.824 ; \mathrm{p}>0.05, \mathrm{r}=.24)$. In other words, it can be stated that the peer mediation training has been effective in the difference between the self-efficacy pre-test and post-test scores of the 
experimental group and that the impact has also continued for the follow-up measurements. In conclusion, it can be put forth that the peer mediation training has been effective in the higher conflict resolution skills, locus of control and self-efficacy levels of secondary school students who have taken this training in comparison with those who have not. Moreover, it is also possible to state that this impact is long-lasting.

\section{Discussion and Conclusion}

The objective of the present study was to examine the impacts of peer mediation training on selfefficacy, locus of control and conflict resolution skills. It was determined in this study when students who have taken the peer mediation training were compared with those who have not that there is an increase in their conflict resolution skills which also continued during the follow-up measurements. It was observed as a result of a literature survey that there are many studies which put forth that conflict resolution and peer mediation training programs improve conflict resolution skills (Arslan, 2014; Ateș, 2014; Ay et al., 2019; Çavuş-Kasik, 2012; Çoșkuner, 2008; Damirchi, 2014; Johnson et al., 1995; Lane-Garon, 2000; Gülkokan, 2011; Kılıçarslan \& Atıc1, 2015; Koruklu, 1998; Kutlu, 2016; Mutluoğlu \& Serin, 2012; Sağkal, 2011; Şevkin 2008; Tapan, 2006; Taştan, 2004; Türk, 2008; Türnüklü et al., 2010; Uysal, 2003; Zengin, 2008; Bosworth et al., 1998; Cardoza, 2013; Carruthers et al., 1996; Farrell \& Meyer, 1997; Hart \& Gunty, 1977; Johnson et al., 1997; Johnson et al., 1995; Schaeffer \& Rollin, 2001; Schellenberg, 2005;Smith et al., 2002; Stevahn et al., 1996; Stewart, 2000; Stacey-Cremin, 2001; Thompson, 1996).

Similarly, the meta-analysis studies which put forth the impact of peer mediation, conflict resolution and negotiation skills indicate that these trainings increase conflict resolution skills (Burrell et al., 2003; Johnson \& Johnson, 2001; Wilson et al., 2007; Türk, 2018). It can be stated when these study results are considered alongside the studies with similar results that peer me-diation training can play an important role in supporting students to resolve their own conflicts at schools while also contributing to both their social and emotional developments. Hence, it is observed that the inclusion of these trainings in school-based programs is important.

It was determined in the present study that there is a statistically significant increase in the internal locus of control levels of students who have taken the peer mediation training in comparison with those who have not and that the increase continued during the follow-up measurements. Internal or external perception of the locus of control is responsible with whether the individual feels responsible for his/her own actions or not. If the individual holds himself/herself responsible from his/her own behaviors that individual has internal control; however if he/she relates the outcome of his/her behaviors with other factors outside of his/her own will it means he/she is an individual with external control (Başal \& Dönmez, 1985; Yüksel, 1991). Therefore, it can be put forth that peer mediation model adolescents who are able to resolve the conflicts with their friends by themselves or with the support of a peer will have contributed to taking on more re-sponsibility and being a more internally controlled individual. A transformation from external control to internal control is generally considered as a function of the circumstances and events which strengthen self-efficacy and efficiency (Başal and Dönmez, 1985). It can be put forth that the effective and constructive resolution of conflicts by adolescents through the use of their per-sonal skills contributes to themselves taking on the responsibility of their own behaviors thereby improving their internal control. The periods when adolescence has started that correspond to secondary school years are of critical importance for self-development that is also expressed as identification (Cüceloğlu, 2011). Adolescents who are provided with opportunities for making their own decisions and whose autonomy is supported in social environments such as family and school will have paved their way to becoming individuals with internal control. Contrary to this study, the study by Stacey-Cremin (2001) evaluated the effectiveness of the peer mediation programs applied on 5th grade students, however a statistically significant difference could not be observed in their loci of control. A small number of studies have been determined which examine the impact of peer mediation training on the locus of control. The fact that the effective- 
ness of peer mediation training on developing internal control has been put forth in this study can be considered as a significant contribution to the relevant literature.

It was determined in this study that there is an increase in the self-efficacy levels of students who have taken peer mediation training in comparison with those who have not and that the increase also continued during the follow-up measurements. Türk (2018) carried out a study as a result of which it was put forth that the self-efficacy perception is a statistically significant pre-cursor of conflict resolution skill. It can be expected that the conflict resolution skills will be high for students with high self-efficacy levels and that self-efficacy levels will increase with increasing conflict resolution skill.

A significant number of studies could not be observed as a result of the literature survey carried out with regard to the impact of peer mediation on self-efficacy. However, it is observed that the results obtained can be in parallel with the results of studies that may be related with self-efficacy. Stewart (2000) carried out a study in which it was determined that a similar increase has taken place in the social skills of students subject to peer mediation program and that their interpersonal relations have developed. Similarly, Stacey-Cremin (2001) also determined that the peer mediation program has improved the personal and social skills of students. Schaeffer and Rolin (2001) carried out a study in which it was reported that the conflict resolution program prepared for developing the problem solving and adaptation skills has led to an increase in the interpersonal relations of students. Similarly, Cardoza (2003) determined in their study that stu-dents who have taken peer mediation training display high levels of social-competence. Lane-Garon, YbarraMerlo, Zajac and Vierra (2005) also determined in their studies that there is a statistically significant difference in the social emotional skills for understanding perspective as a result of the conflict resolution and peace training applied.

In conclusion, it was determined that students who have taken the peer mediation training have more effective conflict resolution skills, internal locus of control and self-efficacy levels in comparison with those of students who have not taken this training. Schools play an important role in supporting the cognitive developments of students for the raising of healthy generations in addition to supporting the social and emotional developments of students (Durlak et al., 2011). Hence, it is considered that making these training programs part of the school culture is important for the development of the students. It is thought that including peer mediation trainings as part of the psychological counseling and guidance curricula of the schools will contribute to preventing violence at schools as well as developing the required social and emotional skills. At this point, it can be stated that the awareness and professional competence of school psychological counsels should be increased with regard to peer mediation trainings. Conflict resolution, locus of control and self-efficacy were used as dependent variables in this study. It can be suggested for future studies to examine the impact of peer mediation training on dependent variables such as subjective well-being, school commitment, school climate, peer relations. In addition, longitudinal studies can also be carried out for determining whether the impacts of peer mediation training continue in the long run. A peer mediation training program was not developed in the present study and an already existing program was used. Random assignment was not possible since the peer mediators were selected via sociometry and a semi-experimental study pat-tern was used. This research was conducted with a small study group, so it is difficult to generalize the results. 


\section{References}

Abdi-Golzar, F. (2006). İlköğretim 5. Sinıf öğrencilerine yönelik sorumluluk ölçeğinin geliş̧tirilmesi ve sorumluluk düzeylerinin cinsiyet, denetim odağı ve akademik başarlya göre incelenmesi [Unpublished master's thesis]. Hacettepe University, Ankara.

Arslan, E. (2014). 7. sinıf ögrrencilerine uygulanan bir akran arabuluculuk eğitiminin akran arabulucuların çatışma çözme becerilerine olan etkisinin incelenmesi [Unpublished master's thesis]. Çukurova University, Ankara.

Ateş, N. (2014). Çatışma çözme eğitiminin 6. Sınıf ögrencilerinin çatışma çözme becerileri ve özsayg d düzeylerine etkisi [Unpublished master's thesis]. Haliç University, İstanbul.

Ay Çeviker, Ş., Keskin, H. K., \& Akıllı, M. (2019). Examining the effects of negotiation and peer mediation on students' conflict resolution and problem-solving skills. International Journal of Instruction, 12(3), 717-730. https://doi.org/10.29333/iji.2019.12343a

Başal, H. A. \& Dönmez, A. (1985). Çevre büyüklügü ve 10-12 yaş ilkokul çocuklarında denetim odağ1 (Locus of Control). Eğitim ve Bilim Dergisi, 55(5), 10-19.

Borenstein, M., Hedges, L. V., Higgins, J. P. T. \& Rothstein, H. R. (2009). Introduction to MetaAnalysis. United Kingdom: John Wiley \& Sons Ltd.

Burrell, N., Ziber, C.S., \& Allen, M. (2003). Evaluating Peer Mediation Outcomes in Educational Settings: A Meta-Analytic Review. Conflict Resolution Quarterly, 21(1), 7-26.

Bush, R. A. B. \& Folger, J. P. (2013). Arabuluculuk ve Getirileri. G. Sart. (Çev.). Ankara: Nobel Yayıncılık. (Orijinal çalışma basım tarihi 2004)

Cardoza, D. J. (2013). Peer Mediation and its effects on elementary student perceptions of selfesteem and social competence [Unpublished doctoral thesis]. California State Universty, California.

Carruthers, W. L., Sweeney, B., Kmita, D. \& Harris, G. (1996). Conflict resolution: An examination of the Research literatüre and a model for program evalution. The School Counselor, 44(1), 5-18.

Cohen, J. (1988). Statistical power analysis fort the behavioral sciences. (2nd ed.). New Jersey: Lawrence Erlbaum Associates.

Coşkuner, E. (2008). Barış eğitimi programının öğrenci şiddeti üzerindeki etkilerinin incelenmesi. [Unpublished master's thesis]. Dokuz Eylül University, İzmir.

Cüceloğlu, D. (2011). Insan ve Davranışı Human and Behaviour. İstanbul: Remzi Kitabevi A.Ş.

Çavuş-Kasik, N. (2012). Çatışma çözme ve akran arabuluculuğu eğitim programının benlik saygısı ve çatışma çözme becerilerine etkisi [Unpublished master's thesis]. Ondokuz Mayıs University, Samsun.

Çetin, C., Türnüklü, A. \& Turan, N. (2015). Anlaşmazlıkların çözümünde akran arabuluculuk modelinin dönüştürücü etkileri: Arabulucu öğrenciler gözünden bir değerlendirme. Dokuz Eylül Üniversitesi Sosyal Bilimler Enstitüsü Dergisi, 16(3), 383-411. doi:10.16953/deusbed.97238

Dağ, İ. (2002). Kontrol odağı ölçeği (KOÖ): Ölçek Geliştirme, güvenirlik ve geçerlik çalışması. Türk Psikoloji Dergisi, 17 (49), 77-90.

Damirchi, E. S. (2014). Barış eğitimi programının yedinci sınıf öğrencilerinin çatışma çözme ve iletişim becerilerine etkisi [Unpublished doctoral thesis]. Hacettepe University, Ankara.

Durlak, J. A., Weissberg, R. P., Dymnicki, A. B., Taylor, R. D., \& Schellinger, K. B. (2011). The impact of enhancing students' social and emotional learning: A meta-analysis of schoolbased universal interventions. Child development, 82(1), 405-432.

Farrell, A.D., \& Meyer, A.L. (1997). The effectiveness of a school based curriculum for reducing violence among urban sixth-grade students. American Journal of Public Health, 87(6), 979984.

Göğebakan-Yıldız, D. (2016). Ortaokul düzeyinde uygulanan anlaşmazlık çözümü ve akran arabuluculuk eğitim programının etkililiği (boylamsal bir çalışma). E-International Journal of Educational Research, 7(1), 36-55 doi: 10.19160/e-ijer.41016 
Gülkokan, Y. (2011). Akran arabuluculuk ĕgitiminin ilköğretim öğrenci anlaşmazlıkları üzerindeki etkisinin incelenmesi [Unpublished master's thesis]. Dokuz Eylül University, İzmir.

Hart, J., \& Gunty, M. (1997). The Impact of A Peer Mediation Program On An Elementary School Environment. Peace \& Change, 22(1), 76-92.

İspirgil, G., (2007). The effect of conflict resolution training on students conflicts management strategies with their friends and nonfriends [Unpublished master's thesis]. Abant İzzet Baysal University, Bolu.

Johnson, D. W., Johnson, R., Dudley, B. \& Magnuson, D. (1995). Training elementary school students to manage conflict. The Journal of Social Psychology, 135(6), 673-686.

Johnson, W.D., \& Johnson, R. (2001). Teaching Students To Be peacemakers: A Meta-Analysis. Research Reports. The Annual Meeting of the American Educational Research Association. (Seattle WA. 10-14 April 2001)

Johnson, W.D., \& Johnson, R., Dudley, B., Mitchell, J., Fredrickson, J. (1997). The impact of conflict resolution training on middle school students. The Journal of Social Psychology, I37(1), 11-21.

Kılıçarslan, S. \& Atıcı, M. (2015). Çatışma çözme eğitim programının ilköğretim 6. ve 7. sınıf öğrencilerinin çatışma çözme davranışları üzerindeki etkisi. Ç.Ü. Sosyal Bilimler Enstitüsü Dergisi, 24 (2), 137-158.

Kite, D. (2007). 21. yy'da Arabuluculuk Mediasyon. Mediation in the 21st Century. Kayseri: Kayseri Ticaret Odas1.

Koruklu (Öner), N. (1998). Arabuluculuk eğitiminin ilköğretim düzeyindeki bir grup öğrencinin çatışma çözme davranışlarına etkisinin incelenmesi [Unpublished master's thesis]. Ankara University, Ankara.

Kutlu, A. (2016). Çatışma çözme psikoeğitim programının ortaokul öğrencilerinin, çatışma çözüm becerileri, sürekli öfke ve öfke ifade tarzları üzerindeki etkisi [Unpublished master's thesis]. Mevlana University, Konya.

Lane-Garon, P., Ybarra-Merlo, M., Zajac, J., \& Vierra, T. (2005). Mediators and mentors: partners in conflict resolution and peace education. Journal of Peace Education, 2(2), 183193.

Lane-Garon, S.P. (2000). Practicing peace: The impact of a school-based conflict resolution program on elementary students. Peace and Change, 25(4), 467-482.

Milli Eğitim Temel Kanunu. https://www.mevzuat.gov.tr/MevzuatMetin/1.5.1739.pdf

Moore, C.W. (2016). Arabuluculuk Süreci. Anlaşmazlık Çözümünde Pratik Stratejiler. (T. Kaçmaz ve M. Tercan, Çev.). Ankara: Nobel Akademik Yayıncılık. (Orijinal çalışma basım tarihi 1996)

Mutluoğlu, S. \& Serin, O. (2012). Çatışma çözme eğitim programının ilkokul 5. sınıf öğrencilerinin çatışma çözme becerilerine etkisi. Turkish International Journal of Special Education and Guidance \& Counselling (TIJSEG), 1(1), 1300-7432.

Noaks, J. \& Noaks, L. (2009). School-based peer mediation as a strategy for social inclusion. Pastoral Care in Education, 27(1), 53-61. doi:10.1080/02643940902731880

Özmen, A. (2004). Seçim kuramına ve gerçeklik terapisine dayalı öfkeyle başa çıma eğitim programının ve etkileşim grubu uygulamasının üniversite öğrencilerinin öfkeyle başa çıkma becerileri üzerindeki etkisi [Unpublished doctoral thesis]. Ankara University, Ankara.

Sağkal, A. S., (2011). Barış eğitimi programının ilköğretim 6. sınıf öğrencilerin saldırganlık eğilimleri, empati düzeyleri ve barlşa ilişkin görüşleri üzerindeki etkisinin incelenmesi [Unpublished master's thesis]. Dokuz Eylül University, İzmir.

Schaeffer, S. \& Rollin, A. S. (2001). The evaluation of a community-based conflict resolution program for African American children and adolescents. Research for Educational Reform, 6(1), 33- 50.

Schellenberg, R. C., (2005). School violence: Evaluation of a elementary school peer mediation program [Unpublished doctoral thesis]. Regent Universty, Virgina. 
Smith, W.S., Daunic, P.A., Miller, D.M., \& Robinson, R.T. (2002). Conflict resolution and peer mediation in middle schools: extending the process and outcome knowledge base. The Journal of Social Psychology, 142(5), 567- 586.

Stacey-Cremin, H. (2001). An investigation into whether the 'Iceberg' system of peer mediation training, and peer mediation, reduce levels of bullying, raise self-esteem, and increase pupil empowerment amongst upper primary age children [Unpublished doctoral thesis]. University College, London.

Stevahn, L., Johnson, D.W., Johnson, R., \& Real, D. (1996). The impact of a cooperative or individualistic context on the effectiveness of conflict resolution training. American Educational Research Journal, 33(4), 801-823.

Stewart, J. T. (2000). A formative evaluation of a conflict resolution program utilizing peer mediation training on the knowledge and attitudes of middle school students at a hillsborough county, Florida middle school [Unpublished doctoral thesis]. Universty of Sarasota, Florida.

Şevkin, B. (2008). Müzakere (problem çözme) ve arabuluculuk eğitim programının ilköğretim 4.5. sinıf ögrencilerinin çatışma çözüm stilleri ve saldırganlık eğilimleri üzerindeki etkilerinin incelenmesi [Unpublished master's thesis]. Dokuz Eylül University, İzmir.

Tapan, Ç. (2006). Barış eğitimi programı'nın öğrencilerin çatışma çözme becerileri üzerindeki etkilerinin incelenmesi [Unpublished master's thesis]. Dokuz Eylül University, İzmir.

Taştan, N. (2004). Çatışma çözme ve akran arabuluculuğu eğitimi programlarının ilköğretim altıncı sını ögrrencilerinin çatışma çözme ve akran arabuluculuğu becerilerine etkisi. [Unpublished doctoral thesis]. Ankara University, Ankara.

Taştan, N. (2006). Çatışma Çözme Eğitimi ve Akran Arabuluculuğu. Uygulamalı Grup Rehberliği Programları Dizisi. Ankara: Nobel Yayın Dağıtım.

Telef, B. B. (2011). Öz-yeterlikleri farkl ergenlerin psikolojik semptomlarının incelenmesi [Unpublished doctoral thesis]. Dokuz Eylül University, İzmir.

Thompson, S. M. (1996). Peer mediation: A peaceful solution. School Counselor, 44(2), 151-155.

Türk, F. (2008). Müzakere (problem çözme) ve arabuluculuk eğitim programinın ilköğretim 4. ve 5. sınıf öğrencilerinin çatışma çözüm becerileri üzerinde etkisinin incelenmesi [Unpublished master's thesis]. Dokuz Eylül University, İzmir.

Türk, F. (2013). Akran arabuluculuk eğitiminin lise öğrencilerinin arabuluculuk becerilerine etkisinin incelenmesi [Unpublished master's thesis]. Dokuz Eylül University, İzmir.

Türk, F. (2018). Evaluation of the effects of conflict resolution, peace education and peer medition: A meta-analysis study. International Education Studies, 11(1), 25-43. doi: 10.5539/ies.v $11 \mathrm{n} 1 \mathrm{p} 25$

Türk, F., Türkmen, C., Satıc1, B., Başol, N \& Gümüş, B. (2015). Akran Arabuluculuk Eğitim Programı Psikolojik Danışman El Kitabı. Denizli: İl Milli Eğitim Müdürlüğü Yayınları.

Türnüklü, A. (2005). Lise okul yöneticilerinin çatışma çözüm strateji ve taktiklerinin sosyal oluşturmacılık kuramı perspektifinden incelenmesi. Kuram ve Uygulamada Eğitim Yönetimi, 11 (42), 255-278.

Türnüklü, A. (2007). Sınıf Yönetimi. E. Karip, (Ed.), Öğrenciler Arasındaki Çatışmaların Çözümünde Problem Çözme ve Arabuluculuk içinde (ss.193-232). Ankara: Pegem

Türnüklü, A. \& Şahin, İ. (2002). İlköğretim okullarında öğrenci çatışmaları ve öğretmenlerin bu çatışmalarla başa çıkma stratejileri. Kuram ve Uygulamada Eğitim Yönetimi Dergisi, 30, 283- 302.

Türnüklü, A. \& Şahin, İ. (2004). 13-14 yaş grubu öğrencilerin çatışma çözme stratejilerinin incelenmesi. Türk Psikoloji Yazılarl, 7(13), 45-61.

Türnüklü, A., \& Bekmezci, E. (2010). Sosyal yapılandırmacılığın penceresinden öğrencilerin davranışlarının yönetimi. Ĕ̈itime Baklş Dergisi, 16, 27-31.

Türnüklü, A., Kaçmaz, T., Gürler, S., Kalender, A., Zengin, F. \& Şevkin, B. (2009). The effects of conflict resolution and peer mediation education on students' empathy skills. Education and Science, 34(153), 15-24. 
Türnüklü, A., Kaçmaz, T., Gürler, S., Şevkin, B., Türk, F., Kalender, A. \& Zengin, F. (2010). The effects of conflict resolution and peer mediation training on primary school students level of aggression. Education 3-13, 38(1), 13-22.

Uysal, A. (2003). Şiddet karşıtı programlı eğitimin öğrencilerin çatışma çözümleri, şiddet eğilimleri ve davranışlarına yansıması [Unpublished docotral thesis]. Ege University, İzmir.

Wilson, S. J., \& Lipsey, M. W. (2007). School-based interventions for aggressive and disruptive behavior: Update of a meta-analysis. American Journal of Preventive Medicine, 33(2), 130143.

Zengin, F. (2008). Müzakere (problem çözme) ve arabuluculuk eğitim programının ilköğretim 4.5. sınıf ögrencilerinin çatışma çözüm stilleri ve atılganlı becerileri üzerindeki etkisinin incelenmesi [Unpublished master's thesis], Dokuz Eylül University, İzmir. 